\title{
Pengaruh Pengembangan Karir, Komunikasi Dan Stres Kerja Terhadap Prestasi Kerja Karyawan
}

\author{
Marta Widian Sari \\ Universitas Putra Indonesia YPTK Padang, Indonesia \\ Martawidiansari@upiyptk.ac.id
}

\begin{abstract}
This study aims to find out how much the influence of Career Development, Communication and Work Stress simultaneously and partially to the employee performance. Methods of data collection through surveys and distributing questionnaires, with a sample of 80 employees. The analysis method used is correlation and multiple regression analysis.The result of research obtained by Partial Test ( $t$ test) is obtained: (a) There is a significant influence between career development on employee performance (b) There is significant influence between communication to employee performance, (c) There is significant influence between stress (d) There is significant influence simultaneously between career development, communication and work stress on employee performance. And based on Determination coefficient test (R2) the value is 0,525. This shows that the percentage contribution of career development, communication and job stress variable to work performance variable is $52.5 \%, 47.5 \%$ is influenced by other variables outside this research.Finally the authors suggest companies should pay attention to career development, communication and stress on employees because it can improve the process in work that can lead to the achievement of results or target companies.
\end{abstract}

Keywords: Job performance, Career Development, Communication and Job Stress.

\section{Pendahuluan}

Sebagai sumber daya manusia, karyawan merupakan aset terpenting dibandingkan faktorfaktor produksi lainnya, yakni sebagai penggerak utama berjalannya perusahaan. Kualitas dari sumber daya itu sendiri, salah satunya dapat dilihat dari bagaimana kinerja yang ditunjukkan. Sumber daya yang berkualitas pasti memiliki tingkat kinerja yang tinggi. Namun, tidak semua sumber daya manusia memiliki tingkat kualitas yang sama dalam melaksanakan tugasnya. Prestasi dalam bekerja merupakan salah satu kebutuhan yang ingin dicapai setiap orang dalam bekerja. Prestasi kerja karyawan tidak sama hasilnya, hal ini disebabkan karena setiap karyawan mempunyai kemampuan dan kemauan yang berbeda untuk melaksanakan pekerjaan.

Penilaian prestasi kerja dilakukan bersama pimpinan dan bawahannya. Kinerja sebuah perusahaan merupakan kegiatan yang dilakukan untuk meningkatkan eksistensi perusahaan dalam mencapai tujuan dan sasaran sesuai dengan visi dan misinya Kinerja perusahaan dilakukan dalam menjamin tercapainya sasaran yang ditetapkan perusahaan itu sendiri. Kinerja perusahaan dilakukan untuk mengetahui posisi perusahaan jika terjadi kelambatan, harus segera dicari penyebabnya untuk segera diupayakan mengatasinya akan memberikan dampak langsung terhadap hasil kerja yang dicapai tiap individu. Hal ini berdampak jika sesorang sudah merasakan kepuasan dalam berkerja maka individu tersebut akan selalu berusaha memberikan hasil yang terbaik, begitu juga sebaliknya jika individu yang bersangkutan belum merasakan kepuasan dalam berkerja artinya apa yang di dapatkan dari perusahaan tidak sesuai dengan harapan maka akan memberikan dampak menurunnya semngat dan pengembangan karyawan dalam berkerja. 
Tabel 1. Data Target Dan Realisasi Produk Perkebunan kelapa Sinar Mas Merangin

\begin{tabular}{|c|c|c|c|}
\hline \multirow{2}{*}{ Tahun } & Target Produksi & Pencapaian Produksi & \multirow{2}{*}{ \%Pencapaian } \\
\cline { 2 - 3 } & Ton & Ton & $95 \%$ \\
\hline 2014 & 45360 & 43203 & $99 \%$ \\
\hline 2015 & 45360 & 44726 & $96 \%$ \\
\hline 2016 & 45360 & 43378 & \\
\hline
\end{tabular}

Sumber: Perkebunan Kelapa Sawit Sinar Mas Merangin

Berdasarkan tabel 1 dapat dilihat dari hasil produksi dan persentase perusahaan pada tahun 2014 tidak mencapai target, dimana target perusahaan 45360 ton dan hasil yang dicapai hanya 43203 ton atau sekitar $95 \%$. Pada tahun 2015 hasil produksi hampir mencapai target yang telah ditetapkan yaitu 44726 ton persentase pencapaian 99\%, mengalami peningkatan dari hasil tahun sebelumnya. pada tahun 2016 kembali mengalami penurunan dari tahun sebelumnya hasil tidak memuaskan karena tidak mencapai target yang telah ditetapkan dimana hanya 43378 ton sekitar $96 \%$ mengalami penurunan dari tahun sebelumnya.

Dari keterangan data di atas bahwa tingkat prestasi kerja tidak optimal yang menyebabkan tidak tercapai target produksi yang di tetapkan oleh perusahaan, diduga di sebabkan oleh faktor stres kerja karena terget produksi yang tinggi yang di tetapkan oleh perusahaan. Fenomena ini didukung dengan penelitian sebelumnya yaitu [1] dengan judul Pengaruh Stress Kerja Terhadap Prestasi Kerja Pegawai Di Kecamatan Malinau Kota Kabupaten Malinau. Dan juga di sebabkan kurangnya pengembangan karir pada karyawan didukung dengan penelitian [2] dan [3]. Komunikasi dan expetasi kerja karyawan yang di nilai masih belum optimal yang juga didukung oleh penelitian [4] dan [5]. Fenomena ini kuatkan dengan penelitian yang di lakukan oleh [6] yang mengatakan bahwa stres kerja ada pengaruh yang positif dan signifikan antara stres kerja terhadap prestasi kerja karyawan kecamatan Malinau Kota Kabupaten Malinau.

\section{Tinjauan Pustaka}

\section{Prestasi Kerja}

Sedangkan menurut [7] Prestasi Kerja adalah catatan yang diproleh dari fungsi-fungsi pekerjaan tertentu atau kegiatan tertentu selama kurun waktu tertentu. Fungsi kerja adalah melakukan pekerjaan sesuai dengan jabatannya. Setiap jabatan dalam organisasi panitia mempunyai fungsi kerja yang berbeda sesuai dengan bidangnya.

\section{Pengembangan Karir}

Pengertian pengembangan karir menurut beberapa pendapat : Pengembangan karier (career development) adalah suatu kondisi yang menunjukkan adanya peningkatan status seseorang dalam suatu organisasi pada jalur karier yang telah ditetapkan dalam organisasi yang bersangkutan [8].

\section{Komunikasi}

Menurut [9] komunikasi adalah suatu proses melalui mana individu dalam hubungannya, dalam kelompok, dalam organisasi dan dalam masyarakat menciptakan, mengirimkan, dan menggunakan informasi untuk mengkoordinasi lingkungannya dan orang lain.

\section{Stres Kerja}

Pendapat yang dikatakan oleh [1] bahwa Stress Kerja adalah perasaan yang menekan atau merasatertekan yang dialami karyawan dalam menghadapi pekerjaan. Stress akan tampak dari Simpton antara lain emosi tidak stabil, perasaan tidak tenang, suka menyendiri, sulit tidur, merokok yang berlebihan, tidak bisa rileks, cemas, tegang, gugup, tekanan darah meningkat dan mengalami gangguan pencernaan. 
Dan berikut ini adalah beberapa hasil penelitian yang telah di lakukan mengenai variabel yang bersangkutan, berikut dengan hasil dan juga teknik pengolahan data yang di lakukan demi mendukung dan juga membuktikan dari kebenaran hipotesis.

a. Penelitian yang di lakukan oleh: [10] dengan judul Pengaruh Pengembangan karir terhadap Prestasi Kerja Karyawan Tetap PT. Astra International, Tbk Daihatsu Malang dengan metode Analisis linear berganda dan hasil analisis membuktikan Hasil analisis regresi linier berganda menunjukkan bahwa secara simultan dan parsial variabel Perencanaan Karir, Pengarahan Karir, dan Implementasi Pengembangan Karir mempunyai pengaruh yang signifikan terhadap Prestasi Kerja Karyawan Metode analisis menggunakan Analisis Regresi Berganda.

b. Penelitian yang dilakukan oleh: [3] dengan judul pengaruh pengembangan karir terhadap kinerja pegawai Di Dinas Pengendalian Penduduk dan Keluarga Berencana Kabupaten Bantaeng dengan metode analisa regresi linear berganda, Uji T-test, Uji F serta Uji Koefisien Determinasi (R2). Hasil analisis menunjukan bahwa (1) pengembangan karir berpengaruh positif dan signifikan terhadap kinerja pegawai Di Dinas Pengendalian Penduduk dan Keluarga Berencana Kabupaten Bantaeng (2) pengawasan berpengaruh positif dan signifikan terhadap kinerja pegawai Di Dinas Pengendalian Penduduk dan Keluarga Berencana Kabupaten Bantaeng (3) komitmen pegawai berpengaruh positif dan signifikan terhadap kinerja pegawai Di Dinas Pengendalian Penduduk dan Keluarga Berencana Kabupaten Bantaeng (4) pengembangan karir, pengawasan dan komitmen pegawai berpengaruh positif dan signifikan terhadap kinerja pegawai Di Dinas Pengendalian Penduduk dan Keluarga Berencana Kabupaten Bantaeng.

c. Penelitian yang di lakukan oleh: [4] dengan judul Pengaruh Kepemimpinan Dan Komunikasi Terhadap Kinerja Karyawan Kaltim Pos Samarinda dengan metode Analisis linear berganda dan hasil analisis menunjukkan kepemimpinan dan komunikasi berpengaruh positif dan signifikan terhadap kinerja karyawan, dan komunikasi mempunyai pengaruh dominan terhadap kinerja karyawan.

d. Penelitian yang di lakukan oleh [5] dengan judul pengaruh gaya kepemimpinan transformasional, kerjasama tim dan komunikasi terhadap kinerja karyawan pada Warung Mina Cabang Renon di DenpasarTeknik analisis yang digunakan adalah teknik analisis regresi linier berganda. Hasil pengujian hipotesis menunjukkan bahwa semua hipotesis yang diajukan diterima. Gaya kepemimpinan transformasional berpengaruh positif dan signifikan terhadap kinerja karyawan. Kerjama tim berpengaruh positif dan signifikan terhadap kinerja karyawan. Komunikasi berpengaruh positif dan signifikan terhadap kinerja karyawan.

e. Penelitian yang di lakukan oleh: [1] dengan judul Pengaruh Stress Kerja Terhadap Prestasi Kerja Pegawai Di Kecamatan Malinau Kota Kabupaten Malinau dengan metode korelasi product momen dan regresi linear sederhana dan hasil analisis stress kerja ternyata mempunyai pengaruh terhadap prestasi kerja pegawai pada Kecamatan Malinau Kota Kabupaten Malinau. Kedua, besarnya pengaruh stress kerja terhadap prestasi kerja di Kecamatan Malinau Kota Kabupaten Malinau.

f. Penelitian yang di lakukan oleh: [11] dengan judul Pengaruh Stres Kerja Dan Kepuasan Kerja Terhadap Kinerja Karyawan Pada Pt. Kusuma Satria Dinasasri Wisatajaya Batu-Malang dengan metode Analisis linear berganda dan hasil analisis secara parsial variabel stres kerja terdapat pengaruh dan signifikan sedangkan kepuasan kerja terdapat pengaruh tetapi tidak signifikan terhadap kinerja karyawan pada PT. Kusuma Satria Dinasasri Wisatajaya BatuMalang. Sedangkan secara simultan variabel stres kerja dan kepuasan kerja berpengaruh signifikan terhadap kinerja karyawan pada PT. Kusuma Satria Dinasasri Wisatajaya. 


\section{Kerangka Pemikiran}

Berdasarkan landasan teori dan rumusan masalah penelitian mengidentifikasi bahwa variable independen (X) yaitu Pengembangan Karir, Komunikasi, Stres kerja dan variable dependen (Y) yaitu Prestasi Kerja, dapat digambarkan sebagai berikut :

\section{Hipotesis}

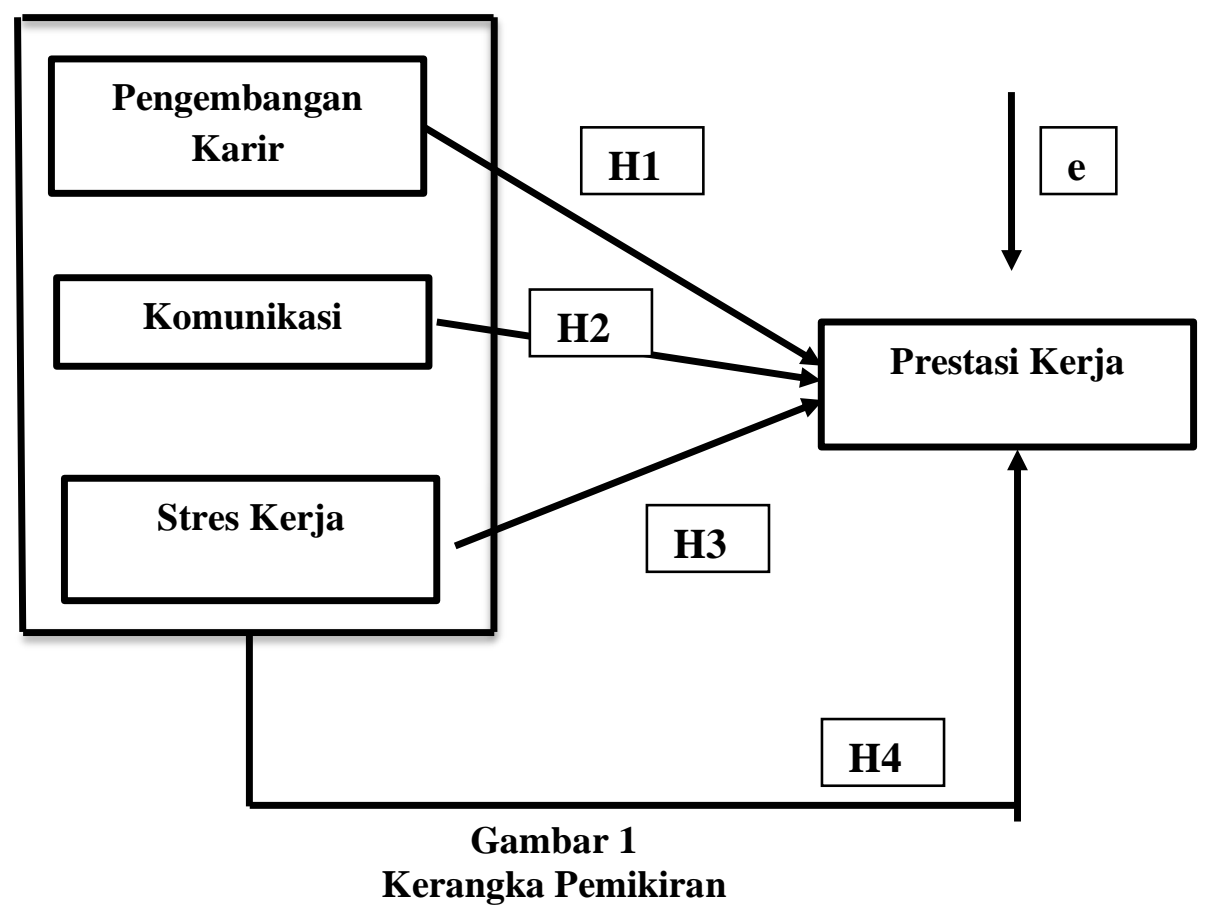

H1. Diduga adanya pengaruh antara pengembangan karir secara signifikan terhadap prestasi kerja pada Perkebunan Kelapa Sawit Sinar Mas .

H2. Diduga adanya pengaruh antara komunikasi secara signifikan terhadap prestasi kerja pada Perkebunan Kelapa Sawit Sinar Mas kabupaten Merangin.

H3. Diduga adanya pengaruh antara stres kerja secara signifikan terhadap prestasi kerja pada Perkebunan Kelapa Sawit Sinar Mas kabupaten Merangin.

H4. Diduga adanya pengaruh antara pengembangan karir, komunikasi dan stres kerja secara simultan terhadap prestasi kerja pada Perkebunan Kelapa Sinar Mas kabupaten Merangin.

\section{Metodologi Penelitian}

\section{Rancangan Kegiatan}

Berdasarkan tujuan penelitian yang telah ditetapkan dengan adanya hipotesis yang hendak diuji, maka jenis penelitian ini adalah penelitian penjelasan (explanatory research).Penelitian ini menggunakan rumus Slovin Berdasarkan hasil perhitungan, maka jumlah sampel yang digunakan sebanyak 80 orang responden. Karena dasar itulah peneliti menentukan jumlah sampel dalam penelitian ini sebanyak 80 responden.

\section{Ruang Lingkup Atau Objek}

Tempat penelitian ini dilakukan di Perkebunan Kelapa Sawit Sinar Mas kabupaten Merangin, Merupakan perusahaan yang memberikan data dan informasi yang diperlukan guna mendukung penulisan ini. 


\section{Teknik Pengumpulan Data}

Teknik Pengumpulan data penelitian ini dilakukan dengan cara penyebaran kuesioner kepada responden dengan panduan kuesioner yang berisi pertanyaan berdasarkan indikator yang diajukan. Penelitian ini bersifat kuantitatif.

\section{Definisi Operasional Variabel}

Defenisi operasional variabel bertujuan untuk menjelaskan makna variabel yang sedang diteliti, adapun devenisi operasional variabel dalam penelitian ini adalah sebagai berikut:

\section{Pengembangan Karir (X1)}

[12] berpendapat bahwa pengembangan karir adalah proses mengidentifikasi potensi karir pegawai dan materi serta menetapkan cara-cara yang tepat untuk mengembangkan potensi tersebut.

2. Komunikasi (X2)

Menurut [13] Komunikasi adalah penyampaian dan pemahaman suatu maksud, apabila komunikasi antara pimpinan dan bawahan tidak terjalin dengan baik maka akan terjadi kesalah pahaman antara keduanya.

3. Stres Kerja(X3)

Menurut [14] menyatakan bahwa stres kerja adalah suatu kondisi dimana terdapat satu atau beberapa faktor di tempat kerja yang berinteraksi dengan pekerja sehingga mengganggu kondisi fisiologis, dan perilaku

\section{Prestasi Kerja (Y)}

Menurut [15] dalam mengatakan bahwa prsetasi kerja yang dihasilkan oleh karyawan/pegawai sesuai dengan kecakapan, kemampuan dalam melaksanakan suatu pekerjaan dan mengevaluasi secara objektif dan dilakukan secara berkala.

\section{Teknik Analisis}

Analisis data yang digunakan sebagai berikut:

1. Analisis Deskriptif Menurut [16] statistik deskriptif adalah "statistik yang digunakan untuk menganalisis data dengan cara mendeskripsikan atau menggambarkan data yang telah berkumpul sebagaimana adanya tanpa bermaksud membuat kesimpulan yang berlaku untuk umum atau generalisasi

2. Pengujian Hipotesis

a) Uji t (parsial) Uji t dilakukan untuk menguji signifikasi masing-masing variabel bebas secara parsial atau untuk mengetahui variabel bebas mana yang lebih berpengaruh diantara kedua variabel $(\mathrm{X})$ terhadap variabel terikat $(\mathrm{Y})$.

b) Uji F (Simultan) Perhitungan uji F berdasarkan pada hitungan komputer program SPSS windows. [16] menyatakan bahwa uji $\mathrm{F}$ digunakan untuk menguji secara simultan apakah adanya pengaruh antara variabel Pengembangan Karir (X1) Komunikasi (X2), dan Stres Kerja (X3) dengan Prestasi kerja karyawan (Y) itu signifikan atau tidak .

\section{Hasil dan Pembahasan}

\section{Analisis Regresi Linear Berganda}

Analisis regresi digunakan untuk melihat pengaruh variabel independen: Pengembangan Karir $\left(\mathrm{X}_{1}\right)$, Komunikasi $\left(\mathrm{X}_{2}\right)$ dan Stres Kerja $\left(\mathrm{X}_{3}\right)$ secara simultan terhadap variable dependen: Prestasi Kerja (Y) dengan asumsi variable independen lain dianggap konstan. Hasil analisis seperti yang terlihat pada tabel berikut ini: 
Tabel 2. Hasil Regresi Berganda Variabel Pengembangan Karir $\left(X_{1}\right)$, Komunikasi $\left(X_{2}\right)$ dan Stres Kerja $\left(\mathbf{X}_{3}\right)$ Terhadap Prestasi Kerja $(\mathbf{Y})$

Coefficients $^{\mathrm{a}}$

\begin{tabular}{|c|c|c|c|c|c|c|c|}
\hline \multirow[t]{2}{*}{ Model } & \multicolumn{2}{|c|}{$\begin{array}{c}\text { Unstandardized } \\
\text { Coefficients }\end{array}$} & $\begin{array}{l}\text { Standardized } \\
\text { Coefficients }\end{array}$ & \multirow[t]{2}{*}{$\mathbf{t}$} & \multirow[t]{2}{*}{ Sig. } & \multirow[t]{2}{*}{$\mathbf{R}$} & \multirow[t]{2}{*}{$\begin{array}{c}\text { R } \\
\text { Square }\end{array}$} \\
\hline & B & Std. Error & Beta & & & & \\
\hline (Constant) & 2,362 & 3,453 & & ,684 & ,496 & \multirow{4}{*}{$.736^{\mathrm{a}}$} & \multirow{4}{*}{.542} \\
\hline Pengembangan Karir & ,886 & ,069 & ,072 & 1,257 &, 018 & & \\
\hline Komunikasi & ,796 &, 081 & ,744 & 9,818 &, 000 & & \\
\hline Stres Kerja & ,237 & ,092 & ,200 & 2,583 &, 012 & & \\
\hline
\end{tabular}

Sumber : Hasil Pengolahan SPSS versi 21.

Pada tabel diatas dapat dilihat bahwa nilai konstanta (a) sebesar 2,362 sedangkan koefisien regresi Pengembangan Karir (X1) sebesar 0,886, Komunikasi (X2) sebesar 0,796, dan Stres Kerja (X3) sebesar 0,237 dari nilai ini dapat diformulasikan dalam bentuk persamaan regresi dibawah ini:

Formula : $\mathrm{Y}=\mathrm{a}+\mathrm{b} 1 \mathrm{X} 1+\mathrm{b} 2 \mathrm{X} 2+\mathrm{b} 3 \mathrm{X} 3+\mathrm{e}$

Sehingga diperoleh persamaan regresi untuk pengaruh variabel Pengembangan Karir, Komunikasi, dan Stres kerja terhadap Prestasi Kerja sebagai berikut:

$\mathrm{Y}=2,362+0,086 \mathrm{PK}+0,796 \mathrm{~K}+0,237 \mathrm{ST}$

Interpretasi berdasarkan persamaan tersebut dapat diartikan sebagai berikut:

1. Nilai konstanta sebesar 2,362 artinya jika Pengembangan Karir $\left(X_{1}\right)$, Komunikasi $\left(X_{2}\right)$ dan Stres Kerja $\left(\mathrm{X}_{3}\right)$ tetap maka prestasi kerja $(\mathrm{Y})$ nilainya adalah sebesar 2,362 satuan bobot.

2. Koefisien regresi variable pengembangan karir 0,886 dan bernilai positif ini dapat di artikan bahwa jika pengembangan karir ditingkatkan satu (1) poin maka akan meningkatkan prestasi kerja karyawan sebesar 0,886 dengan indikasi variable lain dianggap nol.

3. Koefisien regresi variabel komunikasi 0.796 dan bernilai positif ini dapat di artikan bahwa jika komunikasi ditingkatkan satu (1) poin maka akan meningkatkan prestasi kerja karyawan sebesar 0.796 satuan bobot.

4. Koefisien regresi variabel Stres Kerja 0.237 jika Stres Kerja ditingkatkan satu (1) poin maka akan menigkatkan Prestasi kerja karyawan sebesar 0.237 dengan indikasi variable lain di anggap nol.

5. Berdasarkan tabel di atas diperoleh angka $R^{2}$ (Adjusted $R$ square) sebesar 0,542 atau $54,2 \%$, hal ini menunjukkan bahwa persentase sumbangan variabel independen pengembangan karir $\left(\mathrm{X}_{1}\right)$, komunikasi $\left(\mathrm{X}_{2}\right)$ dan Stres Kerja $\left(\mathrm{X}_{3}\right)$ terhadap variabel dependen Prestasi Kerja $(\mathrm{Y})$ sebesar 0,525 atau $52,5 \%$. Sedangkan sisanya sebesar $47,5 \%$ dipengaruhi oleh variabel lain di luar penelitian ini.

\section{Uji Hipotesis}

\section{Pengujian Hipotesis Secara Persial (Uji t)}

Uji t parsial digunakan untuk mengetahui apakah variabel-variabel independen secara parsial berpengaruh nyata atau tidak terhadap variabel dependen. Uji t dilakukan untuk pengujian hipotesis dengan membandingkan nilai sig dengan $\alpha$ yang diajukan yaitu $95 \%$ atau $\alpha<0,05$. Hipotesis diterima jika nilai sig $<\alpha 0,05$.

Dari table 2 dapat dilihat hasil uji hipotesis dengan melihat $t_{\text {hitung }}$ dapat dilihat hasil sebagai berikut :

1. pengaruh pengembangan karir, terhadap prestasi kerja, berdasarkan hasil tabel coefficient 4.18 di atas menunjukan signifikan sebesar $0.018<\alpha=0,05$. Berdasarkan pengujian H1 menunjukan pengembangan karir, komunikasi dan stres kerja terhadap prestasi kerja memiliki probilitas lebih kecil dari $\alpha=0,05$,maka Ha diterima $\mathrm{HO}$ ditolak artinya variabel 
pengembangan karir, komunikasi dan stres kerja secara bersama-sama berpengaruh positif dan signifikan terhadap prestasi kerja karyawan.

2. pengaruh komunikasi terhadap prestasi kerja, berdasarkan hasil analisis pada tabel 4.18 diatas menunjukkan signifikan sebesar $0,000<\alpha=0,05$. Berdasarkan pengujian $\mathrm{H} 2$ menunjukan pengembangan karir memiliki nilai probabilitas lebih kecil dari $\alpha=0,05$, maka Ha diterima HO ditolak artinya variabel pengembangan karir berpengaruh positif dan signifikan terhadap prestasi kerja karyawan.

3. Pengaruh Stres Kerja terhadap prestasi kerja, berdasarkan hasil analisis pada tabel 4.18 menunjukkan signifikan komunikasi sebesar $0,012<\alpha=0,05$, maka Berdasarkan pengujian H3 menunjukan komunikasi memiliki nilai probabilitas lebih kecil dari $\alpha=0,05$, maka $\mathrm{Ha}$ diterima H0 ditolak artinya variabel komunikasi berpengaruh positif dan signifikan terhadap prestsi kerja karyawan.

4. pengaruh pengembangan karir, komunikasi dan stres kerja terhadap prestasi kerja 4.18 menunjukkan signifikan stres kerja sebesar $0,003<\alpha=0,05$. Berdasarkan pengujian $\mathrm{H} 4$ menunjukan stres kerja memiliki nilai probabilitas lebih kecil dari $\alpha=0,05$, maka Ha diterima Ho ditolak artinya variabel stres kerja berpengaruh positif dan signifikan terhadap prestasi kerja karyawan.

\section{Pengujian Hipotesis Secara Bersama-Sama/Serempak (Uji F)}

Uji koefisien regresi secara bersama-sama dilakukan dengan Uji F (ANOVA). Uji ini digunakan untuk mengetahui apakah variabel independent secara bersama-sama berpengaruh signifikan terhadap variabel dependent. Atau untuk mengetahui apakah model regresi dapat digunakan untuk memprediksi variabel dependent atau tidak. Signifikan berarti hubungan yang terjadi dapat berlaku untuk populasi (dapat digeneralisasikan). Pengujian dilakukan dengan uji F (ANOVA). Uji F menggunakan taraf signifikan 0,05 dengan derajat kebebasan 95\%, alpha $=5 \%$, df $1(\mathrm{k}-1)$ atau $4-1=3$, dan df $2(\mathrm{n}-\mathrm{k})$ atau $83-4=79$, maka hasil yang diperoleh untuk $\mathrm{F}_{\text {tabel }}$ sebesar 2,72

Uji F dimaksud untuk menguji hipotesis dari penelitian yang menyatakan variable pengembangan karir, komuniksi dan stres kerja mempunyai pengaruh signifikan terhadap prestasi kerja. Hasil pengujian hipotesis secara bersama-sama dapat dilihat pada tabel 4.19 sebagai berikut :

Tabel 3. Uji F Variabel Pengembangan Karir $\left(X_{1}\right)$, Komunikasi $\left(X_{2}\right)$ Dan Stres Kerja $\left(X_{3}\right)$ Terhadap Prestasi Kerja Karyawan (Y) Anova $^{a}$

\begin{tabular}{|c|c|c|c|c|c|c|}
\hline \multicolumn{2}{|c|}{ Model } & $\begin{array}{l}\text { Sum of } \\
\text { Squares } \\
\end{array}$ & df & Mean Square & $\mathrm{F}$ & Sig. \\
\hline \multirow{3}{*}{1} & Regression & 1112,379 & 3 & 370,793 & 86,028 &, $000^{\mathrm{b}}$ \\
\hline & Residual & 327,571 & 76 & 4,310 & & \\
\hline & Total & 1439,950 & 79 & & & \\
\hline
\end{tabular}

a. Dependent Variable: prestasi kerja

b. Predictors: (Constant), stres kerja, Pengembangan karir, komunikasi

Sumber: Hasil Penelitian 2019

Hasil penelitian menunjukan bahwa nilai $\mathrm{F}$ sebesar 86,028 dengan tingkat signifikan sebesar 0,000 dimana $<0,05$ maka dapat disimpulkan bahwa semua variabel bebas secara bersama-sama berpengaruh terhadap prestasi kerja karyawan dan hipotesisnya diterima.

Dari tabel diatas dapat dilihat pengujian ini dilakukan dengan cara membandingkan nilai Fhitung dengan Ftabel karena nilai Fhitung lebih besar dari nilai Ftabel (155.444 > 2,50). Maka diperoleh $\mathrm{H}_{o}$ ditolak dan $\mathrm{H}_{\mathrm{a}}$ diterima, yang berarti hal ini dilakukan secara serempak antara Lingkungan Kerja, Disiplin Kerja, Motivasi Kerja dan Kepuasan Kerja berpengaruh signifikan terhadap Prestasi Kerja. 
Tabel 4

Hasil Pengujian Hipotesis Penelitian

\begin{tabular}{|c|c|c|}
\hline Hipotesis & Pernyataan & Keputusan \\
\hline H1 & $\begin{array}{l}\text { Pengembangan karir berpengaruh yang positif dan } \\
\text { signifikan terhadap Prestasi Kerja Karyawan }\end{array}$ & Ditolak \\
\hline $\mathrm{H} 2$ & $\begin{array}{l}\text { Komunikasi berpengaruh yang positif dan } \\
\text { signifikan terhadap Prestasi Kerja Karyawan. }\end{array}$ & Diterima \\
\hline $\mathrm{H} 3$ & $\begin{array}{l}\text { Stres Kerja Karyawan berpengaruh yang positif } \\
\text { dan signifikan terhadap Prestasi Kerja Karyawan. }\end{array}$ & Diterima \\
\hline $\mathrm{H} 4$ & $\begin{array}{l}\text { Terdapat pengaruh yang positif dan signifikan } \\
\text { antara stres kerja terhadap prestasi Kerja } \\
\text { Karyawan. }\end{array}$ & Diterima \\
\hline
\end{tabular}

Sumber: Data diolan sendiri

Analisis Determinasi (Uji $\left.\mathbf{R}^{2}\right)$

Tabel 5

Hasil Analisis Determinasi

Model Summary ${ }^{\mathrm{b}}$

\begin{tabular}{|l|r|r|r|r|}
\hline Model & \multicolumn{1}{|c|}{$\mathrm{R}$} & R Square & $\begin{array}{c}\text { Adjusted R } \\
\text { Square }\end{array}$ & $\begin{array}{c}\text { Std. Error of the } \\
\text { Estimate }\end{array}$ \\
\hline 1 & $.736^{\mathrm{a}}$ & .542 & .525 & 3.04879 \\
\hline
\end{tabular}

Sumber: Hasil Pengolahan SPSS 21

Berdasarkan tabel di atas diperoleh angka $\mathrm{R}^{2}$ (Adjusted $\mathrm{R}$ square) sebesar 0,525 atau 52,5\%, hal ini menunjukkan bahwa persentase sumbangan variabel independen pengembangan karir $\left(\mathrm{X}_{1}\right)$, komunikasi $\left(\mathrm{X}_{2}\right)$ dan Stres Kerja $\left(\mathrm{X}_{3}\right)$ terhadap variabel dependen Prestasi Kerja $(\mathrm{Y})$ sebesar 0,525 atau $52,5 \%$. Sedangkan sisanya sebesar $47,5 \%$ dipengaruhi oleh variabel lain di luar penelitian ini.

\section{Implikasi Hasil Penelitian}

Dari hasil penelitian tersebut dapat diimplikasikan hal-hal sebagai berikut.

1. Pengaruh Pengembangan Karir terhadap Prestasi Kerja Karyawan Pada Perkebunan Kelapa Sawit Sinar Mas Merangin

Dari pengujian hipotesis yang di lakukan dengan menggunakan uji t diketahui Pengembangan Karir memiliki pengaruh yang positif dan signifikan terhadap prestasi kerja karyawan. Hasil penelitian ini menunjukkan hasil yang sama dengan penelitian yang di lakukan oleh [10] dimana hasil penelitian terdapat hubungan yang signifikan antara Pengembangan Karir terhadap Prestasi Kerja Karyawan.

Artinya Dalam upaya meningkatkan pengembangan karir dan prestasi kerja karyawan pada Perkebunan Kelapa Sawit Sinar Mas Merangin diharapkan pimpinan mampu memperhatikan pengembangan karir dengan memperhatikan keluhan karyawan terhadap pengembangan karir yang ada pada ruangan kerja karyawan itu sendiri agar memberikan kenyamanan dalam bekerja sehingga karyawan merasa lebih puas dalam bekerja.

\section{Komunikasi Terhadap Prestasi Kerja Karyawan Pada Perkebunan Kelapa Sinar Mas Merangain}

Dari pengujian hipotesis yang di lakukan dengan menggunakan uji t diketahui komunikasi memiliki pengaruh yang positif dan signifikan terhadap prestasi kerja karyawan. Hasil penelitian ini menunjukkan hasil yang sama dengan penelitian yang di lakukan oleh [3] dimana hasil 
penelitian terdapat hubungan yang signifikan antara komunikasi terhadap Prestasi Kerja Karyawan Di Dinas Pengendalian Penduduk dan Keluarga Berencana Kabupaten Bantaeng.

Artinya Dalam upaya meningkatkan prestasi kerja karyawan pada Perkebunan Kelapa Sawit Sinar Mas Merangin untuk lebih memperhatikan stres kerja yang di alami karyawan, karena stres kerja mempunyai dampak yang sangat besar dalam prestasi kerja karyawan. Stres kerja dapat menurunkan prestasi kerja dari karyawan, dimana stres yang tinggi dapat menurunkan semangat karyawan dalam bekerja. Perusahaan dapat menurunkan tingkat stres dengan beberapa pendekatan, diantaranya dengan meditasi, perbaikan iklim perusahaan seperti meningkatkan nilai-nilai tentang keagamaan dan diadakanya siraman rohani pagi setiap hari sebelum masuk terhadap karyawan dan memberikan hal-hal baru yang dapat meningkatkan motivasi, seperti adanya liburan bersama antar sesama pekerja.

\section{Pengaruh Stres Kerja Terhadap Prestasi Kerja Karyawan Pada Perkebunan Kelapa Sawit Sinar Mas Merangin}

Dari pengujian hipotesis yang di lakukan dengan menggunakan uji t diketahui stres kerja memiliki pengaruh yang positif dan signifikan terhadap prestasi kerja karyawan. Hasil penelitian ini menunjukkan hasil yang sama dengan penelitian yang di lakukan oleh [6] dimana hasil penelitian terdapat hubungan yang signifikan antara stres kerja terhadap prestasi kerja pegawai pada Kecamatan Malinau Kota Kabupaten Malinau.

Artinya Dalam upaya meningkatkan prestasi kerja karyawan pada Perkebunan Kelapa Sawit Sinar Mas Merangin untuk lebih meningkatkan suasana kantor yang baik sehingga komunikasi perlu adanya suasana yang baik antar sesama karyawan agar terciptanya kinerja yang baik di dalam perusahaan.

\section{Pengaruh pengembangan karir, komunikasi dan stres kerja terhadap prestasi kerja karywan pada perkebunan kelapa sawit sinar mas merangin}

Dari pengujian hipotesis yang di lakukan dengan menggunakan uji t diketahui pengembangan karir,komunikasi dan sters kerja memiliki pengaruh yang positif dan signifikan terhadap prestasi kerja karyawan. Hasil penelitian ini menunjukkan hasil yang sama dengan penelitian yang di lakukan oleh [4] dimana hasil penelitian terdapat hubungan yang signifikan antara stres kerja terhadap prestasi kerja karyawan.

Artinya Keterbatasan penelitian ini hanya menggunakan 3 variabel bebas yaitu pengembangan karir, komunikasi dan stres kerja, dan 1 variabel terikat yaitu prestasi kerja karyawan. Diharapkan selalu menerapkan prinsip-prinsip tata kelola yang baik, secara seimbang dengan pembangunan, nilai-nilai dan budaya perusahaan yang tertuang dalam Visi, Misi dan Moto Perkebunan Kelapa Sawit Sinar Mas Merangin

\section{Kesimpulan}

Dari hasil penelitian tentang Pengaruh Pengembangan Karir, Komunikasi dan Stres Kerja Terhadap Prestasi Kerja Karyawan Pada Perkebunan Kelapa Sawit Sinar Mas Merangin di temukan beberapa kesimpulan dari hasil penelitian sebagai berikut:

1. Pengembangan Karir berpengaruh positif dan tidak signifikan terhadap Prestasi Kerja Karyawan Sinar Mas Merangin.

2. Komunikasi berpengaruh positif dan signifikan terhadap Prestasi Kerja Karyawan Sinar Mas Merangin.

3. Stres Kerja berpengaruh positif dan signifikan terhadap Prestasi Kerja Karyawan Sinar Mas Merangin.

4. Pengaruh Pengembangan Karir, Komunikasi dan Stres Kerja Terhadap Prestasi Kerja Karyawan berpengaruh positif dan signifikan terhadap Prestasi Kerja Karyawan Sinar Mas Merangin. 
Jurnal EKOBISTEK, Vol.8, No. 2, Oktober 2019, Hal 56-65, ISSN : 2301-5268 | E-ISSN : 2527-9483

Copyright@2018 6y LPPM UPI YPTK Padang

\section{DAFTAR PUSTAKA}

[1] A. Nurmalasari, "PENGARUH STRESS KERJA TERHADAP PRESTASI," Pemerintah. Integr., vol. 1, no. 3, pp. 102-114, 2015.

[2] E. S. Wahyuni, T. Taufik, and V. Ratnawati, "PENGARUH BUDAYA ORGANISASI, LOCUS OF CONTROL, STRES KERJA TERHADAP KINERJA APARAT PEMERINTAH DAERAH DAN KEPUASAN KERJA SEBAGAI VARIABEL INTERVENING (Studi Empiris Pada Pemerintah Kabupaten Bengkalis)," J. Manaj., vol. 20, no. 2, p. 189, 2017.

[3] T. Joko, R. Munir, and N. Fattah, "YUME : Journal of Management," PENGARUH Pengemb. KARIR, Pengawas. DAN KOMITMEN PEGAWAI TERHADAP KINERJA PEGAWAI DI DINAS Pengendali. Pendud. DAN Kel. BERENCANA KABUPATEN BANTAENG, vol. 2, no. 2, 2019.

[4] M. Kiswanto, "PENGARUH KEPEMIMPINAN DAN KOMUNIKASI TERHADAP KINERJA KARYAWAN KALTIM POS SAMARINDA M.," J. EKSIS, vol. 6, no. 1, pp. 1429-1439, 2010.

[5] L. D. P. Putri and N. K. Sariyathi, "PENGARUH GAYA KEPEMIMPINAN TRANSFORMASIONAL, KERJASAMA TIM DAN KOMUNIKASI TERHADAP KINERJA KARYAWAN WARUNG MINA CABANG RENON,” Manaj. Unud, vol. 6, no. 6, pp. 3398-3430, 2017.

[6] A. Nurmalasari, "Pengaruh Stress Kerja Terhadap Prestasi Kerja Pegawai di Kecamatan Malinau Kota Kabupaten Malinau," eJournal Pemerintah. Integr., 2015.

[7] S. Suharto, "Pengukuran Prestasi Kerja Karyawan Menggunakan Motivasi Pada Badan Pengelolaan Keuangan Daerah Kota Metro," Akuisisi - J. Akunt., 2017.

[8] M. Muspawi, "MENATA PENGEMBANGAN KARIER SUMBER DAYA MANUSIA ORGANISASI Mohamad Muspawi 1," Menata Pengemb. Karier Sumber Daya Mns. Organ. 114, vol. 17, no. 1, pp. 114-122, 2017.

[9] R. Sukarja and Machasin, "Pengaruh Kepemimpinan dan Komunikasi terhadap Kepuasan Kerja dan Kinerja Pegawai Dinas Pendidikan provinsi Riau," J. TEPAK Manaj. BISNIS, vol. VII, no. 2, pp. 270-284, 2015.

[10] D. Wahyuni, H. N. Utami, and I. Ruhana, "KARYAWAN ( Studi pada Karyawan Tetap PT . Astra International, Tbk Daihatsu Malang )," Adm. Bisnis, vol. 8, no. 1, pp. 1-10, 2014.

[11] A. N. Y. Isvandiari, "PENGARUH STRES KERJA DAN KEPUASAN KERJA TERHADAP KINERJA KARYAWAN PADA PT . KUSUMA SATRIA DINASASRI," JIBEKA, vol. 9, no. 1, pp. 9-14, 2015.

[12] S. Susanti, S. Hendriani, and C. Amsal, "Pengaruh Pengembagan Karir dan Kepuasan Kerja Perawat Terhadap Komitmen Organisasi RSUD Hospital Pekan Baru.," Jom Fekon, vol. 1, no. 2, pp. 1-15, 2014.

[13] W. J. Sumaki, R. N. Taroreh, and D. Soepeno, "Pengaruh Disiplin Kerja, Budaya Organisasi, Dan Komunikasi Terhadap Kinerja Karyawan Pt. Pln (Persero) Wilayah Suluttenggo Area Manado," J. Berk. Ilm. Efisiensi, vol. 15, no. 05, pp. 538-549, 2015.

[14] I. G. P. Arnanta and I. W. Mudiartha, "PENGARUH STRES KERJA, KEPUASAN KERJA DAN IKLIM ORGANISASI TERHADAP TURNOVER INTENTION KARYAWAN CV. DHARMA SIADJA," Manaj. Unud, vol. 6, no. 6, pp. 3314-3341, 2017.

[15] R. Hasibuan, "KOMPENSASI TERHADAP PRESTASI KERJA KARYAWAN PT . GARUDA AREA JAYA BATAM," BENING prodi Manaj., vol. 5, no. 1, pp. 39-50, 2018.

[16] Sugiyono, Metode Penelitian Pendidikan (Pendekatan Kuantitaf, Kualitatif dan R\&D. Bandung: Alfabeta, 2014. 